\title{
Difficult encounters around "monkey cheeks": Farmers' interests and the design of flood retention areas in Thailand
}

\author{
Thanaporn Trakuldit $^{1}$ । Nicolas Faysse ${ }^{1,2}$ ()
}

${ }^{1}$ School of Environment, Resources and Development, Asian Institute of

Technology, Bangkok, Thailand

${ }^{2}$ Cirad, G-Eau Research Unit, Montpellier

University, Montpellier, France

\section{Correspondence}

Nicolas Faysse, Asian Institute of

Technology, Bangkok, Thailand.

Email: faysse@cirad.fr

Funding information

Agence Nationale de la Recherche (French National Agency for Research)

\begin{abstract}
Flood retention areas are being increasingly promoted for flood risk management. People living in these areas will accept them if their interests are taken into account. The present study analyses the extent to which farmers' interests were taken into account in two flood retention projects in Thailand. A feasibility study was conducted in preparation for the first project which included public participation. The second project was a pilot project implemented in the same zone at a small scale. Participants in the public participation process and farmers living in proposed flood retention areas were interviewed for the purpose of the present study. Agreement could have been reached between the farmers and the public agencies concerning the flood retention areas. However, the participation process did not enable frank discussion about the conditions under which farmers would accept the project. The second project was designed without public participation and offered very little compensation to farmers. In countries marked by power imbalances in water resources management, public agencies may impose flood retention areas, but the absence of agreements with farmers can reduce the effectiveness of the measure. Reaching such agreements requires challenging the imbalanced power relationships between farmers and public agencies.
\end{abstract}

\section{K E Y W O R D S}

Chao Phraya River Basin, compensation, flood retention area, public participation, Thailand

\section{1 | INTRODUCTION}

In recent decades, increasing attention has been paid worldwide to nonstructural "soft" measures for flood risk management, alone or as a complement to "hard" engineering approaches (Challies, Newig, Thaler, Kochskämper, \& Levin-Keitel, 2016; Wesselink et al., 2015). Nonstructural measures do not require investments in heavy infrastructure but include, for instance, land use planning, flood proofing, and insurance mechanisms. One of these measures is establishing controlled flooding areas to limit possible damage downstream. Compensation schemes are a key to their acceptance by inhabitants in the long term (McCarthy,
Viavattene, Sheehan, \& Green, 2018). When the design of such schemes is part of a public participation process, this can result in a shared understanding of the system and better acceptance by stakeholders of solutions which have been reached jointly (Cassel \& Hinsberger, 2017; Challies et al., 2016).

In Europe, many projects involving flood retention areas have been combined with compensation schemes (Enjolras, Erdlenbruch, Grelot, Kast, \& Thoyer, 2008; van DoornHoekveld et al., 2016; van Staveren, Warner, van Tatenhove, \& Wester, 2014), and the schemes were designed without public participation only in a few cases (Ungvári, Kis, et al., 2013). Much more often, in Europe, 
stakeholders are invited to participate in the design of flood retention areas and of the associated compensation schemes (Edelenbos, Van Buuren, Roth, \& Winnubst, 2017; Rouillard, Reeves, Heal, \& Ball, 2014). The proposed compensation schemes are generally based on payments (Erdlenbruch, Thoyer, Grelot, Kast, \& Enjolras, 2009; Morris, Beedell, \& Hess, 2016), even though farmers may also be interested in other types of support, such as receiving technical advice (Holstead, Kenyon, Rouillard, Hopkins, \& Galán-Díaz, 2017).

In Asia, the development of flood retention areas is very promising. At a time when controversies over the building of large-scale dams have become the rule rather than the exception (Kirchherr, 2018), flood retention schemes may have less disruptive effects on the environment than structural measures. Storing flood water on farmland has been a traditional way to collect water for subsequent agricultural use in Asia (Huang, 2014; van Staveren, 2017; van Staveren, van Tatenhove, \& Warner, 2018). However, only a few cases of controlled flooding of farmland aimed at protecting areas located downstream have been reported to date. Several of these cases are located in China (Huang, 2014). In the past, farmers had no say in the matter and the Chinese government provided no compensation in the case of deliberate flooding (Junya \& Wright, 2013). More recent cases in China have involved some compensation (Xia \& PahlWostl, 2012). An experiment in the creation of a flood retention area was also conducted in Japan but the upscaling process was difficult due to lack of incentives for farmers to get involved (Yoshikawa, 2014).

Public participation processes to discuss the design of flood retention areas and related compensation schemes may be a challenge in many Asian countries, where water resources management is in the hands of centralised and bureaucratic public agencies. Studies have shown time and again that these agencies are unwilling to relinquish their power in order to give more space to public participation on issues such as irrigation management (Molle, Mollinga, \& Wester, 2009; Suhardiman \& Giordano, 2014). In Asian countries which have a tradition of state-centred management of water resources, the shortcomings of public participation processes have been repeatedly underlined not only in the context of the construction of water infrastructures (Fan, 2016; Lawrence, 2012; Singto, Fleskens, \& Vos, 2018), but also in the case of policy design for water resources management (Shah, 2010). Participatory processes run contrary to the incentive structure and organisational culture of centralised bureaucracies (Ricks, 2016). For instance, in Thailand, the Royal Irrigation Department (RID) is a powerful entity in charge of the management of irrigation schemes and has also considerable responsibility for water resources management. The RID has made limited efforts to take into account the interests of farmers in the way it organises participatory irrigation management (Ricks, 2015).

The fact is, there are very few reported cases of public participation in the design of flood retention areas in Asia. The participatory process studied by Te Boekhorst et al. (2010) in China was organised by a nongovernmental organisation. To date, there have been no studies on the extent to which-whether or not in the framework of formal public participation processes-Asian public agencies combine flood retention measures and compensation schemes that meet the interests of farmers located in the areas that will be flooded and hence facilitate their acceptance of the project.

The present paper analyses the extent to which farmers' interests were taken into account in the design process of two flood retention projects in Thailand. The first project began in 2015, when the RID undertook a feasibility study to design large-scale flood retention areas in the central part of the Chao Phraya River Basin (hereafter referred to as the Yom-Nan flood retention project). This project included a formal public participation process. Second, in 2017, the RID implemented a pilot flood retention project in an area located for the most part in Bang Rakam District, and which was covered by the feasibility study. This initiative was called the Bang Rakam Model 60 and did not include a formal public participation process.

\section{I FLOOD RETENTION AREAS IN THAILAND}

\section{1 | Local formulation of the concept}

In Thailand, the concept of flood retention area became famous under the initiative of King Bhumibol Adulyadej in 1995. The original idea was to store water during flood periods in the upper part of the delta area around Bangkok. Storing water enabled to limit damages in downstream areas and to later release fresh water to flush away saline water, which entered from the sea during the dry season. The concept was popularised under the name "monkey cheek," which refers to a monkey storing food in its cheeks to be able to chew it later. This concept was later broadened to include land located far from the seashore.

In Thailand, flood retention areas are now conceived as uncultivated or agricultural lands which are intentionally inundated to protect downstream areas. Residential zones located within flood retention areas need to be protected from flooding and roads raised so that flood water does not submerge them. A system of pumps, canals, and sluice gates enables the control of water storage and release. Flood retention areas are located in low-lying lands, where the inhabitants usually face frequent natural floods. However, in a flood retention area, the artificial flood water can be set to 
be much deeper than the average depth occurring during natural floods. The artificial floods can also last longer. A flood retention area has already been implemented in Bang Ban District, Ayutthaya Province, which is located in the Central Region of Thailand (Sricharo \& Nantiyakul, 2017). Farmers living in this area were not involved in the decision-making process concerning the establishment of the flood retention area (Khamhongsak \& Kuaicharoen, 2013). The Thai government praised these farmers for their "sacrifice" when their land was flooded in order to protect the Bangkok Metropolitan Area (Lebel \& Lebel, 2017) but farmers received very limited compensation.

\section{2 | Two flood retention projects}

The Chao Phraya River Basin is the largest basin in Thailand. The Chao Phraya River begins at the confluence of the Ping and Nan Rivers, and the main tributary of the Nan River is the Yom River (Figure 1). The Bangkok
Metropolitan Area, which is home to more than 15 million inhabitants, is located in the delta of the Chao Phraya River Basin and is particularly exposed to flooding. In the past, flood management policies mainly focused on building storage reservoirs and embankments (Lebel \& Lebel, 2017; Singkran, 2017). In 2011, a major flood occurred in Thailand, which affected 13 million people (Poaponsakorn, Meethom, \& Pantakua, 2015). In 2012, the government earmarked 350 billion baht (approximately US\$ 11.3 bil$\operatorname{lion}^{1}$ ) for the implementation of a master water management plan, which mentioned the creation of flood retention areas.

However, the budget for this plan was cancelled in 2015, after having been criticised for the lack of public participation (Khamhongsak \& Kuaicharoen, 2013). The plan had not been designed following the decree on Public Consultation issued in 2005 by the office of the Prime Minister, which states that development projects must include public consultation. Such a cancellation may appear surprising as in 2014, the Army had taken control of the government and,

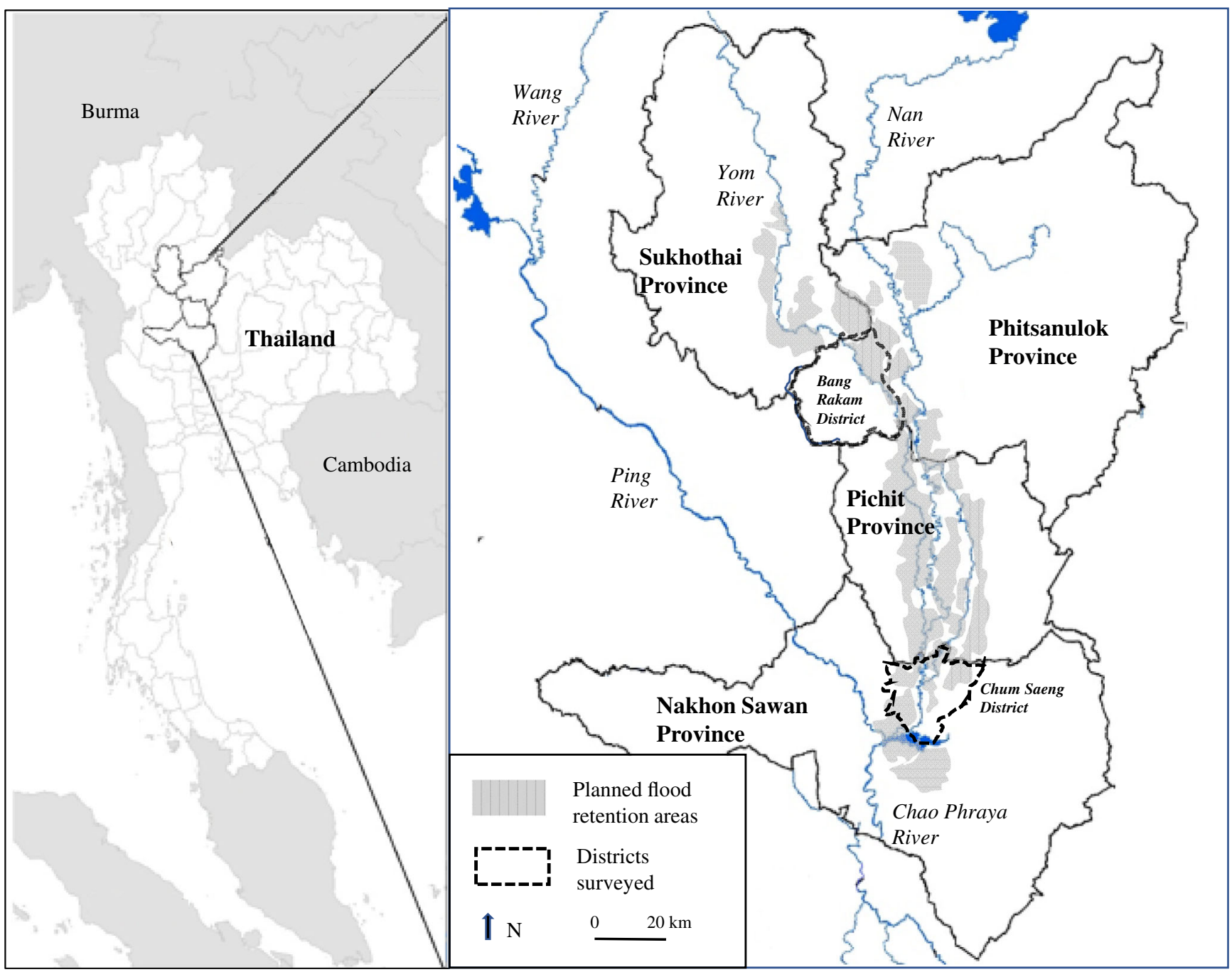

F I G URE 1 Flood retention areas planned in the feasibility study and districts surveyed in the present study 
more generally, in the past, public participation in water resources management has been limited in Thailand (Kanjina, 2015; Ricks, 2015). However, several social movements had been able to oppose the building of dams or the scheduled operation of hydraulic infrastructures (Foran \& Manorom, 2009; Kirchherr, 2018). Therefore, the government paid importance to avoiding national or international criticism of its water policies.

The RID, which is an agency within the Ministry of Agriculture and Cooperatives, was made responsible for the design and operation of flood retention areas. In 2015, the RID assigned a consortium of consulting companies to conduct a feasibility study of the implementation of flood retention areas. The feasibility study involved the preliminary identification of flood retention areas, an environmental impact assessment, an economic assessment, and a public participation process. The feasibility study was completed in April 2017.

The low lands considered in the feasibility study are located in Phichit, Nakhon Sawan, Phitsanulok, and Sukhothai Provinces (Figure 1). These low lands are also located in the downstream parts of the Nan and Yom River Basins. The area considered in the feasibility study encompasses several irrigation schemes. In an irrigation scheme, the RID operates a system of pumps and canals, which makes it possible to provide irrigation water and to control flooding (by closing the gates connecting the river to the canals in case of high flows in the river and, sometimes, by being able to pump out water from the canals into the river). In areas located outside irrigation schemes, farmers may practice rainfed agriculture or they may have their own systems of canals and pumps, which they operate without the intervention of the RID.

There is no large reservoir in the Yom River Basin. Floods are consequently frequent in the rainy season in the downstream part of this basin and in the area where the Yom River merges with the Nan River (Sayaphan, 2014). Farmers living in this region are used to 2-month floods, which usually occur in September and October. They generally grow two rice crops per year when they have access to irrigation and make sure they harvest wet season rice before the flood period (Thongpan, 2013).

The main objectives of the public participation process were to raise the awareness of the inhabitants concerning the Yom-Nan flood retention project and to encourage their acceptance of the project (TEAM and TWI, 2017). Participants were consulted on the characteristics of the project and their proposals were handed to the RID. Thus, the process amounted to organising public hearings with no predetermined impact on decision-making. Because of limited time and budget, the consortium in charge of the feasibility study did not organise workshops at village level. Instead, they created 11 local working teams, which included representatives of the inhabitants and staff from administrations whose responsibilities were related to the project (e.g., departments of the Ministry of Agriculture and Cooperatives). Representatives of the inhabitants were presidents of the subdistrict administrations, ${ }^{2}$ subdistrict headmen (who are nominated by village headmen), and presidents of water user groups. These local working team meetings were thus supposed to function as "mini-publics," which would be able not only to inform the representatives of a wide range of stakeholders about the content of the project, but also to provide recommendations that could later help improve decision-making (Goodin \& Dryzek, 2006).

A series of meetings was organised (Figure 2). First, two introductory meetings were held (one for two provinces) to present the concept of a flood retention area and the participatory process, and to select the members of the local working teams. The local working teams met three times. At each of these team meetings, participants were informed about some of the proposed characteristics of the project and expressed their views. Two meetings concerning the whole project area were held to present the results of the process to the representatives of the inhabitants and to the staff of the public organisations intervening in the project area. Finally, as part of the environmental impact assessment, two surveys were conducted, the first of 607 farms and the second of 815 (farming and nonfarming) households. Farmers and household members were asked about their perception and acceptance of the project.

The Bang Rakam Model 60 started in February 2017 in Bang Rakam District (its name being "60" because 2017 is year 2560 in the Thai calendar) and in neighbouring districts. This pilot experiment was implemented on 42,400 ha. This area belongs to the Yom-Nan irrigation scheme. The Bang Rakam Model 60 was based on the following procedure. First, the RID delivers water to farmers in April instead of May, which is usually the case in the Yom-Nan irrigation scheme. Farmers should start rice cultivation in April and use short-term rice varieties. Thanks to these changes, farmers should be able to harvest before the end of July (instead of in August as they did previously). The fields can then be flooded for up to 4 months between August to November.

Meetings were held in February 2017 in Bang Rakam District to explain the model and in particular the changes to be implemented in terms of the scheduling of farm operations (Figure 2). These meetings took place at the subdistrict level and involved farmers' representatives. The aim of these meetings was not to get farmers' feedback on the model.

The area defined in the Bang Rakam Model 60 was flooded from the end of July to November 2017 (first because of intense rains and then, from mid-August 
FIG URE 2 Timeline of the public participation process and of the implementation of the Bang Rakam Model 60

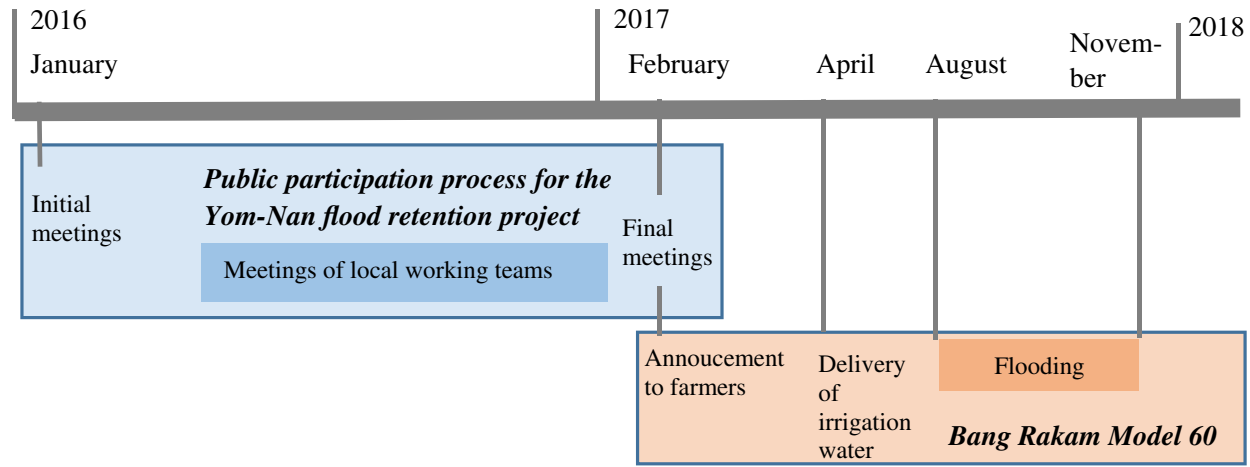

onwards, because of the use of the area for flood retention). The army was present in all meetings and was involved in the implementation of the model. For instance, they took decisions with regard to the operation of sluice gates in cooperation with the RID. In December 2017, the RID judged the experiment to be a success, as 550 million cubic metres had been stored during the flood period. The Prime Minister then declared that a controversial planned dam on the Yom River, whose main role would have been to manage floods, would be cancelled and replaced by the expansion of the Bang Rakam Model (The Nation, 2017).

\section{3 | METHOD}

In order to assess to what extent the two projects took farmers' interests into account, both the processes for designing the projects and their outcomes in terms of meeting farmers' interests were examined (Maskrey, Priest, \& Mount, 2018). In particular, in the public participation process implemented as part of the Yom-Nan flood retention project, two axes of analysis were used. The first axis used the framework proposed by Rowe and Fewer (2000) and asked those who had participated in the public participation process to assess its quality. The second axis used an actororiented approach (Long, 2003) to investigate how issues of importance for farmers were discussed during the public participation process, and to what extent these discussions influenced the project proposed in the final report of the feasibility study.

Data were collected in two areas included in the YomNan flood retention project (Figure 1): Chum Saeng District in Nakhon Sawan Province (in which nine subdistricts were planned to be included in the project) and Bang Rakam District in Phitsanulok Province (in which five subdistricts were planned to be included in the project). We interviewed 19 of the 68 people who participated in the process as representatives of civil society in Chum Saeng District, and 13 of the 33 representatives of civil society involved in the public participation process in Bang Rakam District. Respondents were selected so as to interview at least two people per subdistrict. We first asked the interviewees about the contents of the discussions during the meetings, with regard to issues that had been identified as being of importance for farmers during preliminary interviews. These issues were: the boundaries of the flood retention areas; the maximum duration of floods and the maximum water depth when the areas are used to store flood waters; the amount of financial compensation; the possibility for farmers to obtain irrigation water during the dry season as a compensation; and the protection of roads from flooding.

Second, the interviewed representatives were asked to evaluate the public participation process based on seven criteria (selected from Rowe \& Frewer, 2000): (1) the representativeness of participants; (2) the independence of facilitators, that is, there was no bias in the way meetings were facilitated; (3) the transparency of the process, that is, the objectives of the meetings were clearly stated; (4) the possibility for participants to access the information needed in order to understand the issues discussed during the meetings; (5) early involvement, that is, participation occurred at the outset of the decision-making process; (6) clear task definition, that is, participants clearly understood what was expected of them during meetings; and (7) structured decision-making, that is, there was a clear method to collect the opinions and proposals of participants in order to jointly frame the conclusions of the meetings. The interviewed participants were asked to score each of these criteria from 0 (unsatisfactory) to 5 (very satisfactory) and to explain their assessment. Third, they were asked about the benefits and drawbacks of the Yom-Nan flood retention project and whether they supported it (bearing in mind existing uncertainties about its final characteristics).

An additional 43 farmers were interviewed: 20 farmers from Bang Khian Subdistrict in Chum Saeng District and 23 farmers from Than Nang Ngam Subdistrict in Bang Rakam District. All the farmers interviewed had no or very limited knowledge about the Yom-Nan flood retention project. Moreover, farmers in Bang Rakam District had experienced the artificial floods which occurred in the framework of the Bang Rakam Model 60 but they knew very little about 
the characteristics of the Yom-Nan flood retention project. Thus, in both districts, farmers were invited to give their general opinion on flood retention areas. Farmers were asked about: (a) their understanding of the main benefits and drawbacks of flood expansion areas and (b) whether they agreed or not with the implementation of flood expansion areas which would include their farm land. Finally, we interviewed five members of staff of the companies in charge of the feasibility study and four RID officers at national and provincial level. All interviews took place between September 2017 and April 2018.

\section{4 | RESULTS}

\subsection{Issues discussed during the public participation process}

The consulting companies drew up an initial list of areas to be included in the Yom-Nan flood retention project. During local team meetings, the facilitators asked participants to add or remove areas from the list. Some of the participants had suggested adding areas during the meetings (interviews, Nakhon Sawan Province, November 2017). They told us that they expected farmers would receive financial compensation or that being part of the flood retention project would secure their access to irrigation water in the dry season. Other participants succeeded in having two areas removed from the project because they feared the roads would be damaged (interviews, Phitsanulok Province, November 2017). The total size of proposed flood retention areas increased from 126,030 ha at the outset of the participation process to 189,670 ha in the feasibility study report. The latter comprised 116,380 ha located outside existing irrigation schemes and 73,290 ha located inside irrigation schemes. The planned area was home to approximately 58,000 households.

The consulting companies did not initially specify a maximum duration for which the proposed areas could be used to store flood waters (interview with staff of consulting companies and with participants in Phitsanulok and Nakhon Sawan Provinces, November 2017). In the reports of the local working team meetings, the proposed maximum duration - based on averaging the participants' proposalsdid not exceed 2 months. However, the feasibility study report did not conclude with a proposal concerning the duration. Staff from the consortium originally proposed a maximum flood water depth of $1.5 \mathrm{~m}$ above soil level in agricultural land (information from local team meeting reports). Members of local working teams-surprisinglyproposed to increase this depth (interview with participants in Nakhon Sawan Province, November 2017). Eventually, the reports of the local working team meetings mentioned that the proposed maximum flood water depth (which was also calculated for each local team by averaging the participants' proposals) was between 1.6 and $1.8 \mathrm{~m}$.

The consortium adjusted the project design to conform with the new proposed maximum water levels. As a result, the proposed project in the report of the feasibility study should be able to store 2.049 billion cubic metres (1.326 million cubic metres in areas outside irrigation schemes and 723 million cubic metres in areas within irrigation schemes). This report also stated that the system of gates, which would be installed in areas included in the project, would be used to protect farmers from "small floods," that is, those which corresponded to a return period of less than 5 years. In all local team meetings, participants insisted that flood water should not submerge roads. Local working teams identified the roads that should be raised as part of the project.

Access to irrigation water during the dry season was a key issue for many farmers in the region, for both those located outside irrigation schemes and those located inside these schemes. All 43 farmers we interviewed said that they did not receive sufficient irrigation water during the dry season. During local team meetings, representatives of farmers located outside irrigation schemes said several times that they would accept the project of flood retention areas in exchange for receiving irrigation water during the dry season (interviews with presidents of water user groups in Nakhon Sawan and Phitsanulok Provinces, November 2017). The staff from the consortium and from the RID did not explicitly refuse their proposals during the meetings, but in fact the RID had not planned to provide irrigation water during the dry season to areas outside irrigation schemes, as a form of compensation (interview with staff from the central office of the RID, April 2018).

In Thailand, farmers can obtain financial compensation in the case of natural floods based on a rate defined at national level, which amounted to 6,950 baht per ha in 2017 . However, in 2016, no specific decree had yet been issued for the provision of financial compensation in flood retention areas, which can be flooded intentionally. During the local working team meetings, facilitators asked the participants to make proposals for financial compensation if farm land was flooded before the rice harvest (discussions did not cover compensation if flooding occurred after the rice harvest). Participants said that the compensation should include both production costs and net benefits, however, no specific value was discussed (interviews with participants in Nakhon Sawan and Phitsanulok Provinces, November 2017). The feasibility study report actually mentioned the results of the survey conducted as part of the environmental impact assessment. In this survey, farmers were asked how much they would accept as a financial compensation if their rice field, already four-months old, was flooded. The report 
proposed the average of farmers' answers, which was 28,650 baht per ha. In the feasibility report, production costs were estimated at between 26,800 and 34,400 baht per ha in 2016 (without taking the possible cost of rented land into account, which was estimated at between 6,000 and 12,000 baht per ha) and net profits were estimated at between 10,400 and 14,500 baht per ha. Therefore, the proposed value of 28,650 baht per ha is actually lower than production costs plus net profits, which range between 41,300 and 56,800 baht per ha.

Eventually, the feasibility study report included proposals concerning some of the characteristics of the project which could negatively affect the farmers (the location of flood retention areas and flood depth) and it included a list of roads to be raised as part of the project. However, the report did not include proposals that could be seen as positive from the farmers' points of view. The report did not mention the possibility of access to irrigation water during the dry season as a form of compensation. It acknowledged the need to pay compensation but it did not conclude with a concrete proposal.

\section{2 | Participants' assessment and farmers' acceptance of the project}

Figure 3 shows participants' assessment of the quality of the public participation process. Participants gave high scores to the independence and transparency criteria. However, several participants believed that the RID had already made key choices, for instance concerning the areas that would be included in the project or the fact that the project would be implemented irrespective of the local actors' points of view. Consequently, they generally gave a medium score for the "early involvement" criterion. Representatives gave a low score for the "structured decision-making" criterion because the consultants usually recorded the participants' remarks but no collective decision was reached.

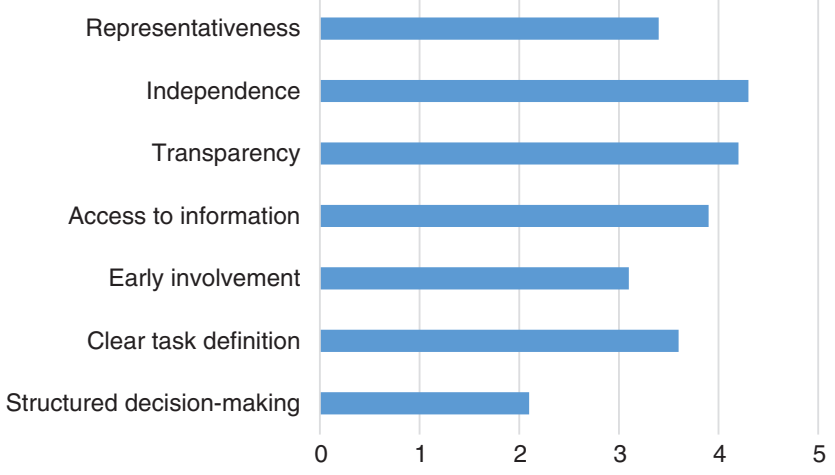

F I G U RE 3 Assessment by representatives of inhabitants of the quality of the public participation processNote: Assessment based on a scale ranging from 0 (unsatisfied) to 5 (very satisfied)
The participation process had other limitations. Six of the representatives interviewed had only an elementary education level. They had difficulty understanding the information provided during the meetings. Moreover, they did not dare to ask questions during the meetings. Because most representatives of inhabitants did not fully understand the project, they did not pass on information about the project to their constituencies (interviews with village headmen and presidents of water user groups in both provinces, November 2017).

Table 1 shows the farmers' assessments of flood retention areas and representatives' assessments of the Yom-Nan flood retention project. Seven farmers disagreed with having their land included in a flood retention area as they considered floods would damage the rice harvest. Four farmers agreed with such a project as they assumed that they would be able to access irrigation water during the dry season in exchange for being part of the project. The majority of farmers did not have sufficient information on flood retention areas to form an opinion about them. The table also shows that the representatives had a much more positive view of the Yom-Nan flood retention project than the farmers had of flood retention projects in general.

The feasibility study report mentioned that $97.9 \%$ of the 815 household members surveyed agreed with the Yom-Nan flood retention project. This report concluded on the wide support of inhabitants for the project. However, in reality, the inhabitants' real acceptance can be called into question, as most farmers we interviewed in the present study did not have a sufficiently clear idea on flood retention areas to have an opinion about the project.

\section{3 | The Bang Rakam Model 60}

In the Bang Rakam Model 60, the RID considers that, since farmers should harvest rice before their farmland is flooded, they should not receive financial compensation. However, in 2017, the RID supported some agricultural extension activities in cooperation with other departments of the Ministry of Agriculture and Cooperatives, such as the promotion of short-term rice varieties of good quality and certification of good agricultural practices (interview with staff from the RID office for the Yom-Nan irrigation scheme, February 2018). During the flood period, farmers are supposed to have an income from fishing, which was actually a major source of income during the rainy season 40 years ago (the dykes of the Yom-Nan irrigation scheme were built between the 1980s and the 2000s).

All the farmers interviewed for the present study told us they had no say in the design and implementation of the Bang Rakam Model 60. One farmer stated that "the Army told me that they will put water in our field" (interview with a farmer in Than Nang Ngam Subdistrict, November 2017). 
T A B L E 1 Assessment of flood retention areas by the farmers and the representatives interviewed

\begin{tabular}{|c|c|c|}
\hline & $\begin{array}{l}\text { Farmers }(N=43) \text { Assessment of flood } \\
\text { retention areas in general }\end{array}$ & $\begin{array}{l}\text { Representatives }(N=32) \text { Assessment } \\
\text { of Yom-Nan flood retention project }\end{array}$ \\
\hline Main benefits & Number of respondents stating benefits & \\
\hline Possibility to fish during the flood period & 3 & 1 \\
\hline Possibility to receive financial compensation & 0 & 5 \\
\hline Main drawbacks & Number of respondents stating drawbacks & \\
\hline Negative impacts on houses and rice fields & 16 & 13 \\
\hline No possibility to get income during the flood period & 1 & 1 \\
\hline Acceptance of the project & Number of respondents & \\
\hline
\end{tabular}

Farmers had a negative view of planting the rice crop in April because rainfall in that month was much lower than in May and they would consequently need to pump more irrigation water. Farmers also pointed out that they had neither fishing equipment nor the necessary fishing skills. They did not succeed in earning a living from fishing during the flood period in 2017 (interview with farmers in Than Nang Ngam Subdistrict, November 2017). Ultimately, in Bang Rakam District, there was a disconnection between the characteristics of the project that emerged after the public participation process and the characteristics of the Bang Rakam Model 60. In particular, representatives of inhabitants had been invited to discuss compensation fees during the participation process but in the end, no financial compensation was included in the Bang Rakam Model 60.

The feasibility report generally gave higher priority to areas located outside existing irrigation schemes for the implementation of flood retention areas than to those located inside irrigation schemes. The reason was that the potential for water storage was higher in the former. However, in 2018, following the Bang Rakam Model, the RID implemented flood retention areas covering a total of 61,120 ha in 10 areas located inside irrigation schemes in Thailand. On the other hand, there was no further advancement in the Yom-Nan flood retention project.

\section{5 | DISCUSSION}

\section{1 | From weaknesses in the participatory process to power imbalances}

Some weaknesses were apparent in the public participation process setup for the design of the Yom-Nan flood retention project, such as the limited number of meetings, the absence of participants' capacity building and unclear linkage with decision-making. These weaknesses led to limited discussion with regard to the types of compensation about which the RID and the farmers could agree.

Despite these shortcomings, farmers did not take the initiative to express their interests or their disagreement with the participation process, thereby underlining the farmers' limited capacity to negotiate with the RID. First, farmers in irrigated schemes were highly dependent on the RID for the allocation of irrigation water. Second, water user groups in the study area were weak and the official representatives of the inhabitants in the process did not always give priority to the interests of their constituencies. This was particularly clear in several of the local working team meetings during which representatives proposed expanding the flood retention area and increasing the maximum flood water depth, even though there was at that time no obvious benefit for inhabitants to be part of the project. The fact is, presidents of subdistrict administrations and headmen are elected by the inhabitants and are not government officers. On the other hand, they receive a salary from the government and, in official meetings, they wear the same uniforms as government officers. Many of these presidents of subdistrict administrations and headmen tend to behave like government officers (Thepkhachon, 2010) and thus give priority to what they believe are the priorities of the government. Eventually, the "mini-publics" that the local working teams aimed to be, had limited impacts in terms of building the capacities of representatives of local inhabitants and in terms of influencing decision-making. They mainly turned out to be a way to give legitimacy to the flood retention project. 
Thus, the relationship between farmers and public agencies in Thailand appears very different from that in Europe, where the relationship is generally more balanced. European farmers have more political power and farmers' organisations and unions are much stronger. As a consequence, some farmers were actively involved in the negotiation over flood retention areas (Roth \& Winnubst, 2014) or even refused them (Thaler, Löschner, \& Hartmann, 2017).

\section{2 | The forced implementation of flood retention areas...another fragile "short-cut"}

Calls for implementing irrigation management transfer around the world have been based on the premise that such reforms could have positive outcomes for both farmers and for the public agencies in charge of the management of irrigation schemes (Rap, 2006). However, in many Asian countries, centralised irrigation agencies did not genuinely negotiate with farmers about the scope and content of reforms to transfer irrigation management (Mukherji et al., 2009). They forced reforms on the farmers, usually trying to implement them in such a way that would not reduce their own power. This "short-cut" has been put forward as one explanation for the mediocre performance of these reforms (Suhardiman \& Giordano, 2014).

Similarly, on paper, flood retention areas in Thailand may be the subject of win-win agreements, which involve not only farmers and the RID, but also the many stakeholders located downstream who will benefit because future floods will be less extensive in downstream areas. However, the choice made in 2018 to focus on a top-down and nonnegotiated implementation of the Bang Rakam Model appears to be a "short-cut" to fast-track the development of flood retention areas without negotiating the scope and content of this measure with farmers. There are several explanations why the RID considered that the Bang Rakam Model could be implemented on a large scale much more easily than the Yom-Nan flood retention project that was the subject of the feasibility study. First, many farmers located outside irrigation schemes produce rainfed rice and would be negatively affected by artificial floods because they cannot change their sowing dates. However, by mid-2018 no regulation had been issued at national level to enable the payment of financial compensation in the case of controlled flooding. Second, the Bang Rakam Model 60 model avoids the costly building of the infrastructure which would be needed for the development of flood retention areas outside irrigation schemes. Third, the RID considered that since no infrastructure was to be built, there was no need for a formal public participation process. Fourth, officers from the RID declared they had more legitimacy to undertake top-down initiatives in irrigation schemes where they delivered irrigation water to farmers free of charge (interviews with staff of the RID office for the Yom-Nan irrigation scheme, November 2017).

Thus, the Bang Rakam Model avoided lengthy negotiation with farmers about possible compensation associated with the development of flood retention areas. In the end, the RID considered flood management a new "hydraulic mission" (Molle et al., 2009), which required no changes in the way it interacted with farmers.

However, the Bang Rakam Model 60 faced uncertainties and thus appeared as a fragile short-cut. First, in 2018, there was no specific legal framework for this model, in particular, no regulation had been issued to force farmers to start growing dry season rice in April and to harvest it before August. Second, if land is flooded for 4 months, farmers have only 8 months to complete two rice crops, which requires a tight agenda. Therefore, in the absence of some form of compensation, farmers located in irrigated schemes may eventually oppose the use of their land for flood retention. Third, simulations run by Jamrussri and Toda (2017) showed the limited impacts of the Yom-Nan flood retention project on the flood patterns under the hypothesis that the project would enable the storage of one billion cubic metres of water. Thus, implementing flood retention areas only inside irrigation schemes located in the downstream part of the Yom and Nan River Basins (involving a planned stored volume of 723 million cubic metres) could have limited impacts on the global patterns of flood expansion in the Chao Phraya River Basin.

In countries marked by power imbalances between farmers and the public agencies responsible for water resources management, the agencies may be tempted to implement flood retention areas by force without paying attention to farmers' interests. However, if the public agencies attempt to implement such areas without paying genuine attention to farmers' interests, the development of flood retention areas may have the same mediocre and fragile results as the reforms designed to transfer irrigation management. The risk is that the concept of flood retention areas becomes another item on the already long list of concepts for water resources management which: (a) were successful in a limited number of cases, and (b) were nevertheless immediately heralded as a promising solution for the whole world; and (c), which at best, had limited positive outcomes-often because of problems that were actually not related to the concept per se-in many other cases (Shah, 2010; Shah, Makin, \& Sakthivadivel, 2001).

\section{6 | CONCLUSION}

The development of "monkey cheeks" is becoming a key component of water resources management policies in Thailand. However, opportunities for agreements between farmers and the RID were not discussed in detail and 
exploited in the public participation process conducted during the feasibility study and in the Bang Rakam Model 60. The public participation process was more than just a "failed encounter": it actually led to a biased interpretation of farmers' positions toward the project. The decision of the RID to move forward with the implementation of flood retention areas without paying attention to farmers' interests may enable the rapid implementation of this measure in the short term, but equally may jeopardise the success of the measure in the longer term.

In countries with a tradition of state-centred water management, how to set up processes to genuinely take into account the interests of rural inhabitants, and especially those of farmers, in the design of flood retention areas is still an open question. Well-structured public participation processes that meet quality criteria is one step forward. However, on their own, such processes are unlikely to be sufficient to identify and reach agreement among stakeholders, unless they are accompanied by the empowerment of rural inhabitants in their relationship with public agencies.

\section{ACKNOWLEDGEMENT}

This work was supported by the Agence Nationale de la Recherche (French National Agency for Research) as part of the DOUBT project.

\section{ENDNOTES}

${ }^{1}$ In May 1, 2018 US dollar $=31.8$ baht.

${ }^{2}$ In Thailand, the main administrative units are, from the local level up: subdistrict, district, province, and region.

\section{ORCID}

\section{Nicolas Faysse (D) https://orcid.org/0000-0002-5683-8473}

\section{REFERENCES}

Cassel, M. A., \& Hinsberger, M. (2017). Flood partnerships: A participatory approach to develop and implement the flood risk management plans. Journal of Flood Risk Management, 10(2), 164-172.

Challies, E., Newig, J., Thaler, T., Kochskämper, E., \& LevinKeitel, M. (2016). Participatory and collaborative governance for sustainable flood risk management: An emerging research agenda. Environmental Science \& Policy, 55(2), 275-280.

Edelenbos, J., Van Buuren, A., Roth, D., \& Winnubst, M. (2017). Stakeholder initiatives in flood risk management: Exploring the role and impact of bottom-up initiatives in three 'room for the river' projects in The Netherlands. Journal of Environmental Planning and Management, 60(1), 47-66.

Enjolras, G., Erdlenbruch, K., Grelot, F., Kast, R., \& Thoyer, S. (2008). Flood management at the basin level in France: Sustainability of local risk-sharing policies. Presentation made at the World Water Congress, 7-September 12, 2008, Vienna, Austria.

Erdlenbruch, K., Thoyer, S., Grelot, F., Kast, R., \& Enjolras, G. (2009). Risk-sharing policies in the context of the French flood prevention action Programmes. Journal of Environmental Management, 91(2), 363-369.

Fan, M. F. (2016). Environmental justice and the politics of risk: Water resource controversies in Taiwan. Human Ecology, 44(4), 425-434.

Foran, T., \& Manorom, K. (2009). Pak Mun dam: Perpetually contested. In F. Molle, T. Foran, \& M. Käkönen (Eds.), Contested waterscapes in the Mekong region: Hydropower, livelihoods and governance (pp. 55-80). London, England: Earthscan.

Goodin, R. E., \& Dryzek, J. S. (2006). Deliberative impacts: The macro-political uptake of mini-publics. Politics and Society, 34(2), 219-244.

Holstead, K. L., Kenyon, W., Rouillard, J. J., Hopkins, J., \& GalánDíaz, C. (2017). Natural flood management from the farmer's perspective: Criteria that affect uptake. Journal of Flood Risk Management, 10(2), 205-218.

Huang, G. (2014). A comparative study on flood management in China and Japan. Water, 6(9), 2821-2829.

Jamrussri, S., \& Toda, Y. (2017). Simulating past severe flood events to evaluate the effectiveness of nonstructural flood countermeasures in the upper Chao Phraya River basin, Thailand. Journal of Hydrology: Regional Studies, 10, 82-94.

Junya, M., \& Wright, T. (2013). Sacrificing local interests: Water control policies of the Ming and Qing governments and the local economy of Huaibei, 1495-1949. Modern Asian Studies, 47(4), $1348-1376$

Kanjina, S. (2015). Collaborative water governance in Thailand: much ado about nothing? (PhD thesis). University of Hohenheim, Stuttgart, Germany.

Khamhongsak, L., \& Kuaicharoen, W. (2013). From Bang Ragam, Bang Ban to Nakhon Pathom: Where is people? Bangkok, Thailand: Foundation for Ecological Recovery.

Kirchherr, J. (2018). Strategies of successful anti-dam movements: Evidence from Myanmar and Thailand. Society and Natural Resources, 31(2), 166-182.

Lawrence, S. (2012). The Nam Theun 2 controversy and its lessons for Laos. In F. Molle, T. Foran, \& M. Käkönen (Eds.), Contested waterscapes in the Mekong region: Hydropower, livelihoods and governance (pp. 81-110). London, England: Earthscan.

Lebel, L., \& Lebel, P. (2017). Policy narratives help maintain institutional traps in the governance of floods in Thailand. International Journal of Water Resources Development, 34(4), 1-16.

Long, N. (2003). Development sociology: Actor perspectives. London, England: Routledge.

Maskrey, S., Priest, S., \& Mount, N. (2018). Towards evaluation criteria in participatory flood risk management. Journal of Flood Risk Management, 12, 1-14. https://doi.org/10.1111/jfr3.12462

McCarthy, S., Viavattene, C., Sheehan, J., \& Green, C. (2018). Compensatory approaches and engagement techniques to gain flood storage in England and Wales. Journal of Flood Risk Management, 11(1), 85-94.

Molle, F., Mollinga, P., \& Wester, P. (2009). Hydraulic bureaucracies and the hydraulic mission: Flows of water, flows of power. Water Alternatives, 2(3), 328-349.

Morris, J., Beedell, J., \& Hess, T. M. (2016). Mobilising flood risk management services from rural land: Principles and practice. Journal of Flood Risk Management, 9(1), 50-68. 
Mukherji, A., Fuleki, B., Shah, T., Suhardiman, D., Giordano, M., \& Weligamage, P. (2009). Irrigation reform in Asia: A review of 108 cases of irrigation management transfer. Colombo, Sri Lanka: International Water Management Institute.

Poaponsakorn, N., Meethom, P., \& Pantakua, K. (2015). The impact of the 2011 floods, and flood management on Thai households. In Resilience and recovery in Asian disasters (pp. 75-104). Tokyo, Japan: Springer Ed.

Rap, E. (2006). The success of a policy model: Irrigation management transfer in Mexico. The Journal of Development Studies, 42(8), $1301-1324$.

Ricks, J. I. (2015). Pockets of participation: Bureaucratic incentives and participatory irrigation management in Thailand. Water Alternatives, 8(2), 193-214.

Ricks, J. I. (2016). Building participatory organizations for common pool resource management: Water user group promotion in Indonesia. World Development, 77, 34-47.

Roth, D., \& Winnubst, M. (2014). Moving out or living on a mound? Jointly planning a Dutch flood adaptation project. Land Use Policy, 41, 233-245.

Rouillard, J. J., Reeves, A. D., Heal, K. V., \& Ball, T. (2014). The role of public participation in encouraging changes in rural land use to reduce flood risk. Land Use Policy, 38, 637-645.

Rowe, G., \& Frewer, L. J. (2000). Public participation methods: A framework for evaluation. Science, Technology \& Human Values, 25 (1), 3-29.

Sayaphan, C. (2014). Land use when basic infrastructure change in bang Rakam District, Phitsanulok province. Journal of Social Science Research, 37(1), 171-198.

Shah, T. (2010). Taming the anarchy: Groundwater governance in South Asia. Washington, DC: Resources for the Future Press.

Shah, T., Makin, I., \& Sakthivadivel, R. (2001). Limits to leapfrogging: Issues in transposing successful river basin management institutions in the developing world. In M. Svendsen (Ed.), Irrigation and River Basin management: Options for governance and institutions (pp. 31-49). Wallingford, England: CAB International.

Singkran, N. (2017). Flood risk management in Thailand: Shifting from a passive to a progressive paradigm. International Journal of Disaster Risk Reduction, 25, 92-100.

Singto, C., Fleskens, L., \& Vos, J. (2018). Institutionalizing participation in water resource development: Bottom-up and top-down practices in southern Thailand. Water, 10(6), 781.

Sricharo, T., \& Nantiyakul, P. (2017). Water resource administration to promote the monkey cheek project of the irrigation Department in Ayutthaya Province. EAU Heritage Journal Social Science and Humanities, 7(2), 277-288.

Suhardiman, D., \& Giordano, M. (2014). Is there an alternative for irrigation reform? World Development, 57, 91-100.

Te Boekhorst, D. G., Smits, T. J., Yu, X., Li, L., Lei, G., \& Zhang, C. (2010). Implementing integrated river basin management in China. Ecology and Society, 15(2), 23. https://www.ecologyandsociety. org/vol15/iss2/art23/

TEAM \& TWI. (2017). Final report of monkey cheek project on lowland area above Nakhon Sawan province [In Thai]. Unpublished document, Bangkok.
Thaler, T., Löschner, L., \& Hartmann, T. (2017). The introduction of catchment-wide co-operations: Scalar reconstructions and transformation in Austria in flood risk management. Land Use Policy, 68, 563-573.

The Nation. (2017). Kaeng Suea Ten Dam shelved as Cabinet addresses flooding. Newspaper article retrieved in May 2018. Retrieved from http://www.nationmultimedia.com/detail/national/30334865

Thepkhachon, P. (2010). Status of village and sub-district headmen according to the local administration act of 1914 [In Thai]. Journal of Thai Ombudsman, 3(1), 59-78.

Thongpan, S. (2013). The adaptation strategies of farmers in frequently flooded areas in Chumsang District, Nakhon Sawan. Parichart Journal, 26(3), 78-89.

Ungvári, G., Kis, A., Kaderják, P., Keszthelyi, A., Mezősi, A., Kerekes, L., ... Vollaro, M. (2013). Floods and water logging in the Tisza River Basin (Hungary). Deliverable D 4.2 EPI-Water Research Project. Unpublished document. Retrieved from http:// www.feem-project.net/epiwater/docs/epi-water_DL_4-2.pdf

van Doorn-Hoekveld, W., Goytia, S., Suykens, C., Homewood, S., Thuillier, T., Manson, C., ... van Rijswick, H. (2016). Distributional effects of flood risk management-A cross-country comparison of preflood compensation. Ecology and Society, 21(4), 26. https://www.ecologyandsociety.org/vol21/iss4/art26/

van Staveren, M. F. (2017). Bringing in the floods: A comparative study on controlled flooding in the Dutch, Bangladesh and Vietnamese deltas. ( $\mathrm{PhD}$ thesis). Wageningen University, Wageningen, Netherlands.

van Staveren, M. F., van Tatenhove, J. P., \& Warner, J. F. (2018). The tenth dragon: Controlled seasonal flooding in long-term policy plans for the Vietnamese Mekong delta. Journal of Environmental Policy and Planning, 20(3), 267-281.

van Staveren, M. F., Warner, J. F., van Tatenhove, J. P., \& Wester, P. (2014). Let's bring in the floods: De-poldering in The Netherlands as a strategy for long-term delta survival? Water International, 39(5), 686-700.

Wesselink, A., Warner, J., Syed, M. A., Chan, F., Tran, D. D., Huq, H., ... Zegwaard, A. (2015). Trends in flood risk management in deltas around the world: Are we going 'soft'? International Journal of Water Governance, 3(4), 25-46.

Xia, C., \& Pahl-Wostl, C. (2012). Understanding the development of flood management in the middle Yangtze River. Environmental Innovation and Societal Transitions, 5, 60-75.

Yoshikawa, N. (2014). Can paddy fields mitigate flood disaster? Possible use and technical aspects of the Paddy field dam. In Social-ecological restoration in Paddy-dominated landscapes (pp. 197-207). Tokyo, Japan: Springer Ed.

How to cite this article: Trakuldit T, Faysse N. Difficult encounters around "monkey cheeks": Farmers' interests and the design of flood retention areas in Thailand. J Flood Risk Management. 2019; e12543. https://doi.org/10.1111/jfr3.12543 